\title{
Comparision of Various Vasodilators Regimen During Radial Corornary Angiogram: A Prospective Randomised Trial
}

Rabi Malla ${ }^{1}$, Bishal KC ${ }^{2}$, Chandramani Adhikari ${ }^{1}$, Binay K Rauniyar ${ }^{1}$, Deepak Limbu ${ }^{1}$, Bibek Baniya ${ }^{1}$, Sunil Dhungel ${ }^{2}$, Khagendra Jung Shah ${ }^{2}$, Sobita Khadka ${ }^{1}$, Sabita Aryal ${ }^{1}$, Pratikshya Joshi ${ }^{1}$, Aseem bhattrai ${ }^{3}$

${ }^{1}$ Department of Cardiology, Shahid Gangalal National Heart Centre, Bansbari, Kathmandu, ${ }^{2}$ Department of Cardiology, National Academy of Medical Sciences, Bir Hospital, Kathmandu, ${ }^{3}$ Department of biochemistry, Tribhuvan University Teaching Hospital, Kathmandu

\section{DOI Name}

http://dx.doi.org/10.3126/jaim.v5i1.17065

\section{Keywords}

Vasodilators, radial coronary angiogram,

nitroglycerine, verapamil

\section{Citation}

Rabi Malla, Bishal KC, Chandramani Adhikari, et al. Comparison of various vasodilators regimen during radial coronary angiogram: a prospective randomised trial. Journal of Advances in Internal Medicine 2016;05(01):11-14

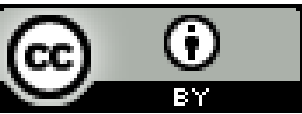

This work is licensed under a Creative Commons Attribution 3.0 Unported License.

\section{Background and Aims:}

Coronary intervention through radial artery is a preferred over femoral route. Different vasodilators are used to prevent radial artery spasm. Till date there is no study to compare the effects of various vasodilator regimes during radial coronary angiogram in Nepal. We aim to compare the efficacy of different vasodilator in our patients.

\section{Methods and Result:}

This is a single centre, prospective randomized trial between Verapamil, Nitroglycerine (GTN) and cocktail (Verapamil with GTN). All the patient undergoing coronary angiogram via radial approach, without the contraindication were randomized by a computer generated randomization protocol. Patient undergoing coronary procedures via the radial artery were divided into three groups. Patients in group A received intra-arterial cocktail ( $2.5 \mathrm{mg}$ of Verapamil plus $100 \mathrm{mcg}$ Nitroglycerine in $10 \mathrm{ml}$ of normal saline), patients in group B received Verapamil $(5 \mathrm{mg})$ and patient in group $\mathrm{C}$ received Nitroglycerine $(200 \mathrm{mcg})$. Heparin of $3000 \mathrm{U}$ was given intravenously in all three groips. Altogether 207 patients underwent transradial coronary angiogram, 203 were randomized after exclusion. Over all Radial artery spasm was reported in 28 patients (13.79\%). There was no statistically significant difference in spasm between the three regimens however when grading, there was significant higher grade of spasm in Verapamil group (13.23\%, P value $<0.05)$. When comparing Verapamil and GTN separately there was significant higher spasm $(21 \%$ vs $7 \%$, P value $<0.05$ ) with higher grades of spasm in verapamil group.

\section{Conclusion:}

Intra arterial vasodilators are frequently used as a spasmolytic during TransRadial angiogram. Our study showed that there is no difference in spasm when chosen between cocktail, verapamil and GTN. However while grading the spasm; there was greater propensity of high grade spasm among the verapamil users.

\section{INTRODUCTION}

First reports of radial coronary angiography was by Lucian Campeau in 1989 and radial percutaneous coronary intervention (PCl) by Ferdinand Kiemeneij in 1992 after which there was an increase in the use of transradial access (TRA) around the world. ${ }^{1,2,3}$ Previous studies have shown that transradial artery approach for coronary artery catheterization and intervention to be safe, easy and effective, as well as cost effective. ${ }^{4}$ Patients also prefer transradial route in comparison to the femoral access because of lower incidence of back and access site pain and earlier ambulation. ${ }^{5,6}$ The advantages we get from the radial route has some demerits also and it

\footnotetext{
* Corresponding author Bishal KC,

National Academy of Medical Sciences, Bir Hospital, Kathmandu, Nepal Email:bishalk@gmail.com
} 
is not devoid of complications. The problem which are faced are unsuccessful radial access, coronary catheterization failure, pulse deficit, radial artery occlusion, dissection, and spasm. ${ }^{1,3,7,8,9}$ The most common of these is the radial spasm ${ }^{8,9}$ causing patient discomfort and even procedure failure. There is high propensity of spasm in the radial artery because of its anatomic property. Its wall is thick and consists of smooth muscle in concentric layer and the cells have high density of alpha-1 receptors. This both properties makes radial artery highly susceptible to spasm. ${ }^{10}$ The reported incidence of radial artery spasm rages from $15-30 \%$ even in the centers highlt experienced with the procedure. ${ }^{11}$ Prevention of the spasm is possible by various premedications. ${ }^{11}$ Worldwide there has been a lot of studies of spasmolytics which has shown the benefit. $4,5,6,9,11,12,13,14$ Among these studies it has been recommended by Kiemeneij et al. ${ }^{11}$ that the spasm is significantly reduced by $34-14 \%$ by the use of cocktail with intra-arterial nitroglycerin and verapamil. Radial access for coronary intervention has been in practice in Nepal for last several years there has been no study regarding the different vasodilator regimen for the prevention of radial artery spasm during the procedure. We report a prospectively randomized study to compare the spasmolytic effects on the radial artery with different premedications, with nitroglycerin alone, verapamil alone and nitroglycerin plus verapamil in radial coronary angiogram.

\section{MATERIALS AND METHODS}

Study was conducted for three months from 2015 June 16 to September 17. Altogether 207 patients undergoing elective coronary angiogram from the radial route were randomized into three different vasodilator regimen. All patients above the age of 18 undergoing radial coronary angiogram with hemodynamic stability were included.

Exclusion criteria included:

1. Abnormal Allens test

2. Pregnancy

3. Hemodynamic Instability

4. Acute $\mathrm{MI}$ or unstable angina needing emergent cardiac catheterization

5. Hypotension (systolic blood pressure below $90 \mathrm{~mm} \mathrm{Hg}$ ),

6. Significant bradycardia (heart rate below 50 beats/min),

7. Severe left ventricular dysfunction (left ventricular ejection fraction less than 35\%)

\section{Acute lung edema}

The baseline characteristics, including patients' age, gender, body weight, body height, serum cholesterol and triglyceride level, the rate of diabetes and smoking, blood pressure, were compared in three groups. Ethical approval was obtained and all patients gave informed consent to this procedure.

Randomization was done by computer generated box randomization protocol. Radial coronary angiogram was performed via right or left route according to the operator's preference. After local anesthetic injection radial artery was punctured and sheath was inserted. Then according to randomization protocol, the patients were divided into three groups of vasodilator regimen. Group A received Cocktail of Verapamil $2.5 \mathrm{mg}+$ GTN $100 \mathrm{mcg}$, Group B received Verapamil$5 \mathrm{mg}$ and Group C received GTN- $200 \mathrm{mcg}$. All patients in three group received $3000 \mathrm{U}$ of heparin via intravenous route.

\section{Definitions}

Spasm was graded according to the operative perceived resistance, Maneuverability of the catheters and degree of pain perception by the patients.

Pain score was defined as the patient's assessment of pain during radial artery sheath removal, where I denote nothing felt; II, noticeable sensation but no pain; III, mild pain; IV, significant pain; and $\mathrm{V}$, unbearable pain. ${ }^{11}$

\section{Statistical Analysis}

Variables were presented as mean \pm standard deviation. ANOVA was used for analysis of the difference in the rate of radial spasms between the three groups. An SPSS software program was used for performing the analysis. A p value $<0.05$ was considered statistically significant.

\section{RESULTS}

Altogether 214 coronary angiograms were performed. Seven underwent angiogram via femoral route. Two hundred seven underwent angiogram via radial route and four were rejected due to abnormal anatomy and radial loop. Two hundred and three patients were randomized into three vasodilator regimens. Sixty five were included in group A, 68 in group $B$ and 70 in group $C$.

Table 1 shows the baseline characteristics, including patients' age, gender, serum cholesterol and triglyceride level, the rate of diabetes and smoking, blood pressure and rate of right and left handed approach. No significant difference in baseline parameters was found between these three groups. Overall radial artery spasm was noted in $14 \%$ of the patients. Nine 
patients in group A (13.8\%), 14 patients in group B $(20.5 \%)$ and 5 patients in group $C(7 \%)$ showed radial spasms. The spasm difference noted was not statistically significant. There was high rate of spasm in female as compared to male ( $20 \%$ vs $9 \%, P<0.05)$. There is no statistically significant difference of radial spasm between groups $A$ and $B(p>0.05)$ and groups $A$ and $C$ ( $p>0.05$ ); however there is strong statistically significant difference between groups $B$ and $C(p<0.05)$. When grading spasm significant higher grade of spasm was noted in group $B$ as compared to group $A$ and group $C(p<0.05)$. Regarding the pain during sheath removal more pain was noted in group $B$ as compared to group A and group $C(p<0.05)$.

Table 1: Baseline characteristics

\begin{tabular}{|c|c|c|c|c|}
\hline & $\begin{array}{l}\text { Group A } \\
\text { (Cocktail } \\
\text { Regimen) }\end{array}$ & $\begin{array}{c}\text { Group B } \\
\text { (Vera- } \\
\text { pamil) }\end{array}$ & $\begin{array}{c}\text { Group C } \\
\text { (GTN) }\end{array}$ & $p$-value \\
\hline Mean & $\begin{array}{c}55.96 \pm \\
10.1\end{array}$ & $\begin{array}{c}54.57 \pm \\
10.9\end{array}$ & $\begin{array}{c}56.37 \pm \\
9.0\end{array}$ & $>0.05$ \\
\hline Male & 44 & 43 & 37 & \multirow[t]{2}{*}{$>0.05$} \\
\hline Female & 21 & 25 & 33 & \\
\hline Hypertensive & 29 & 31 & 37 & \multirow{2}{*}{$>0.05$} \\
\hline Normotensive & 36 & 37 & 33 & \\
\hline Diabetic & 11 & 5 & 15 & \multirow{2}{*}{$>0.05$} \\
\hline Non Diabetic & 54 & 63 & 55 & \\
\hline Present & 4 & 6 & 6 & \multirow{2}{*}{$>0.05$} \\
\hline Absent & 61 & 62 & 64 & \\
\hline Smoker & 15 & 15 & 19 & \multirow[b]{2}{*}{$>0.05$} \\
\hline Non Smoker & 50 & 53 & 51 & \\
\hline Right & 62 & 66 & 69 & \multirow[b]{2}{*}{$>0.05$} \\
\hline Left & 3 & 2 & 1 & \\
\hline Mean & $\begin{array}{c}92.47 \pm \\
15.89\end{array}$ & $\begin{array}{c}88.48 \pm \\
12.34\end{array}$ & $\begin{array}{c}88.30 \pm \\
18.74\end{array}$ & $>0.05$ \\
\hline
\end{tabular}

Patients in group A received, $100 \mathrm{mcg}$ of nitroglycerin and 2.5 $\mathrm{mg}$ of verapamil via sheath, group $B$ received $5 \mathrm{mg}$ of verapamil and group C $200 \mathrm{mcg}$.

\section{DISCUSSION}

Due to the presence of dual blood supply to the hand, radial route for coronary catheterization and intervention is relatively safe. ${ }^{3,5,13,15,16}$ Prevention is better than cure and when it comes to radial artery spasm it holds true. The prevention of spasm is easy than to control when it occurs. ${ }^{8}$

He and yang classification classifies the radial artery into type III artery graft with high propensity for spasm and also as stated above due to abundance of the alpha receptors slight cathecholamine release during pain or anxiety can induce radial spasm. ${ }^{17}$ Many studies done in the past have used different spasmolytic regimens. ${ }^{5,8,9,16}$ In one of the similar studies publish by Kiemeneij et al. ${ }^{14}$ which was a prospective study proved that intra-arterial administration of $5 \mathrm{mg}$ of verapamil and $200 \mathrm{mcg}$ of nitroglycerin reduced the occurrence and severity of radial artery spasm. The data showed the evidence of benefit of verapamil in the prevention of spasm but concern still remains regarding the negative inotropic and chronotropic effects of verapamil. The VITRIOL study ${ }^{18}$ states that The preventive use of verapamil may be unnecessary for transradial procedures. The omission of prophylactic verapamil may not only reduce the rate of potential complications related to the drug but also allow the safe extension of the transradial method to those with contraindications to verapamil. So there has been a lot of reluctance in the use of verapamil as spasmolytics. Study done by Chen et al showed that nitroglycerine alone is also effective as compared to placebo in prevention of radial artery spasm. ${ }^{19}$ Mechanism by which the nitroglycerine causes vasodilation is by by activating guanylyl cyclase and increasing cGMP. ${ }^{20}$ Nitroglycerine has also been compared with the diltiazem and was found to be more effective. ${ }^{21}$ Our data showed that the nitroglycerine is more effective than verapamil and the cocktail of both in preventing spasm. In this study more spasm was found among the female which may be due to the hormonal effect or due to the low pain threshold but the exact cause is still not known. Further larger study requires confirming this.

\section{Study Limitations}

There are few limitations of this study:

1. Not placebo controlled

2. Operators not blinded

3. Due to the different threshold of pain there might be difference in spasm and grading of spasm

4. This is a single center study

5. The follow up of the patient was not done

In conclusion, we recommend that the nitroglycerine be used a preferred spasmolytics during radial coronary angiogram. However larger study using large population in multicenter setting is required to confirm the findings of this study. 


\section{REFERENCES}

1 Campeau L. Percutaneous radial artery approach for coronary angiography. Catheterization and cardiovascular diagnosis. 1989 Jan 1;16(1):3-7.

2 Kiemeneij F, Laarman GJ. Transradial artery PalmazSchatz coronary stent implantation: results of a singlecenter feasibility study. American heart journal. 1995 Jul $31 ; 130(1): 14-21$

3 Kiemeneij F, Laarman GJ, de Melker E. Transradial artery coronary angioplasty. American heart journal. 1995 Jan 31;129(1):1-7.

4 Caputo RP, Simons A, Giambartolomei A, Grant W, Fedele $K$, Abraham S, Felice P, Reger MJ, Walford GD, Esente P. Safety and efficacy of repeat transradial access for cardiac catheterization procedures. Catheterization and cardiovascular interventions. 2001 Oct 1;54(2):188-90.

5 Ludman PF, Stephens NG, Harcombe A, Lowe MD, Shapiro LM, Schofield PM, Petch MC. Radial versus femoral approach for diagnostic coronary angiography in stable angina pectoris. The American journal of cardiology. 1997 May 1;79(9):1239-41.

6 Cooper CJ, El-Shiekh RA, Cohen DJ, Blaesing L, Burket MW, Basu A, Moore JA. Effect of transradial access on quality of life and cost of cardiac catheterization: a randomized comparison. American heart journal. 1999 Sep 30;138(3):430-6

7 Kiemeneij F, Laarman GJ, Odekerken D, Slagboom T, van der Wieken R. A randomized comparison of percutaneous transluminal coronary angioplasty by the radial, brachial and femoral approaches: the access study. Journal of the American College of Cardiology. 1997 May 1;29(6):126975.

8 Goldberg SL, Renslo R, Sinow R, French WJ. Learning curve in the use of the radial artery as vascular access in the performance of percutaneous transluminal coronary angioplasty. Catheterization and cardiovascular diagnosis. 1998 Jun 1;44(2):147-52.

9 Hildick-Smith DJ, Lowe MD, Walsh JT, Ludman PF, Stephens NG, Schofield PM, Stone DL, Shapiro LM, Petch MC. Coronary angiography from the radial arteryexperience, complications and limitations. International journal of cardiology. 1998 May 15;64(3):231-9.

10 He GW, Yang CQ. Characteristics of adrenoceptors in the human radial artery: clinical implications. The Journal of thoracic and cardiovascular surgery. 1998 May 31;115(5):1136-41.

11 Kiemeneij F, Vajifdar BU, Eccleshall SC, Laarman G, Slagboom T, Wieken RV. Evaluation of a spasmolytic cocktail to prevent radial artery spasm during coronary procedures. Catheterization and cardiovascular interventions. 2003 Mar 1;58(3):281-4.

12 Cowling MG, Buckenham TM, Belli AM. The role of transradial diagnostic angiography. Cardiovascular and interventional radiology. 1997 Mar 1;20(2):103-6.

13 Wu CJ, Lo PH, Chang KC, Fu M, Lau KW, Hung JS. Transradial coronary angiography and angioplasty in Chinese patients. Catheterization and cardiovascular diagnosis. 1997 Feb 1;40(2):159-63.

14 Kiemeneij F, Vajifdar BU, Eccleshall SC, Laarman G, Slagboom $T$, van der Wieken R. Measurement of radial artery spasm using an automatic pullback device. Catheterization and cardiovascular interventions. 2001 Dec 1;54(4):437-41.

15 Stella PR, Kiemeneij F, Laarman GJ, Odekerken D, Slagboom T, Van der Wieken R. Incidence and outcome of radial artery occlusion following transradial artery coronary angioplasty. Catheterization and cardiovascular diagnosis. 1997 Feb 1;40(2):156-8.

16 Spaulding $C$, Lefevre $T$, Funck $F$, Thebault B, Chauveau M, Hamda KB, Chalet Y, Monsegu J, Tsocanakis O, Py A, Guillard N. Left radial approach for coronary angiography: results of a prospective study. Catheterization and cardiovascular diagnosis. 1996 Dec 1;39(4):365-70.

17 He GW, Yang CQ. Comparison among arterial grafts and coronary artery: an attempt at functional classification. The Journal of thoracic and cardiovascular surgery. 1995 Apr 30;109(4):707-15.

18 Hizoh I, Majoros Z, Major L, Gulyas Z, Szabo G, Kerecsen G, Korda A, Molnar F, Kiss RG. Need for Prophylactic Application of Verapamil in Transradial Coronary Procedures: A Randomized Trial The VITRIOL (Is Verapamil In TransRadial Interventions OmittabLe?) Trial. Journal of the American Heart Association. 2014 Apr 22;3(2):e000588

19 Chen CW, Lin CL, Lin TK, Lin CD. A simple and effective regimen for prevention of radial artery spasm during coronary catheterization. Cardiology. 2005 Nov 24;105(1):43-7.

20 Ignarro LJ, Kadowitz PJ. The pharmacological and physiological role of cyclic GMP in vascular smooth muscle relaxation. Annual review of pharmacology and toxicology. 1985 Apr;25(1):171-91.

21 Shapira OM, Xu A, Vita JA, Aldea GS, Shah N, Shemin RJ, Keaney JF. Nitroglycerin is superior to diltiazem as a coronary bypass conduit vasodilator. The Journal of thoracic and cardiovascular surgery. 1999 May 31;117(5):906-11. 